\title{
SOLID WASTE MANAGEMENT: FIRST REPORT ON GARBAGE PROBLEM IN DODA REGION OF JAMMU AND KASHMIR, INDIA
}

\author{
Wahied Khawar Balwan \\ Govt. Degree (Postgraduate) College Bhaderwah, Jammu and Kashmir \\ Neelam Saba, Nitesh Singh \\ Govt. Degree College Doda, Jammu and Kashmir \\ Nazia Rasool \\ Co-ordinator, Environmental Sciences, \\ Cluster University Jammu, Jammu and Kashmir
}

\begin{abstract}
Waste has been a major environmental issue everywhere ever since the onset of Industrial revolution. In Doda region of Jammu and Kashmir, due to the increase in the population and the standard of living of people, there has been a tremendous increase in the quantity and variety of waste generation like all other areas of India. There has been rapid increase in the generation of Municipal Solid Waste (MSW) due to increased urbanization. High standards of living of everincreasing population have resulted in an increase in the quantity and variety of waste generated, particularly in urban areas. It is now being realized that if waste generation continues recklessly at this very pace, then it would become rampant and alarming very soon and possibly beyond rectification. Management of solid waste has, therefore, become very important in order to minimize the detrimental and lasting aftermaths of solid waste. Solid waste (i.e., waste other than liquid or gaseous) can be classified as Municipal, Industrial, Agricultural, Medical/Bio-medical, Chemical, Mining, Radioactive, Metallurgical, Poultry/Animal and Sewage sludge.
\end{abstract}

Key Words: Management, Bio-garbage, Solid waste, Municipal waste, Mining waste, Medical Waste and Sewage sludge.

\section{INTRODUCTION}

Waste has been a major environmental issue everywhere ever since the onset of Industrial revolution. In developing countries like India, there is a rapid increase in Municipal Solid Waste (MSW) due to rapid urbanization. In Doda region of Jammu and Kashmir, India, due to the increase in the population and the standard of living of people, there has been a colossal increase in the quantity and variety of waste generated. The composition of municipal solid waste varies greatly from municipality to municipality, and it changes significantly with time. These different compositions that contribute to Municipal Solid Waste (MSW) are called 'Municipal Solid Waste (MSW) Streams'. In municipalities which have a well-developed waste recycling system, the waste stream mainly consists of intractable wastes such as plastic film and nonrecyclable packaging materials.

Solid Waste Management (SWM) has become one of the crucial parameters of urbanization. India has recognized its importance and has set-up 'Clean India Mission'.

The quantity of municipal waste generated from urban settlement is a function

of human development index which in turn depends on the life expectancy, gross

domestic product and education indices (Chandrappa and Das, 2012; Kumar, 2016).

Municipal Solid Waste is the most complex heterogeneous solid waste stream, in contrast with more homogeneous waste streams, such as industrial or agricultural waste (Rasool and Balwan, 2020; Wang and Nie, 2001). The quantity of municipal solid waste is invariably higher in the developed nations compared to the developing nations. Typical waste characteristics of the developing nations are (1) high waste densities, (2) high moisture contents, (3) large organic fraction, (4) cities with sweeping as well as open ground storage characterized by large amount of dust and dirt. (Chandrappa and Das, 2012).

The World Bank assessment of collection coverage quoted on their website that 30 to $60 \%$ of all the urban solid waste in developing countries is uncollected and less than $50 \%$ of the population is served. The poor state of Solid Waste Management in urban areas of developing countries is now not only an environmental problem but also a major social handicap (Daskalopoulos et al., 1998; Rasool and Balwan, 2020). 
International Journal of Engineering Applied Sciences and Technology, 2020

Vol. 5, Issue 7, ISSN No. 2455-2143, Pages 157-173

Published Online November 2020 in IJEAST (http://www.ijeast.com)

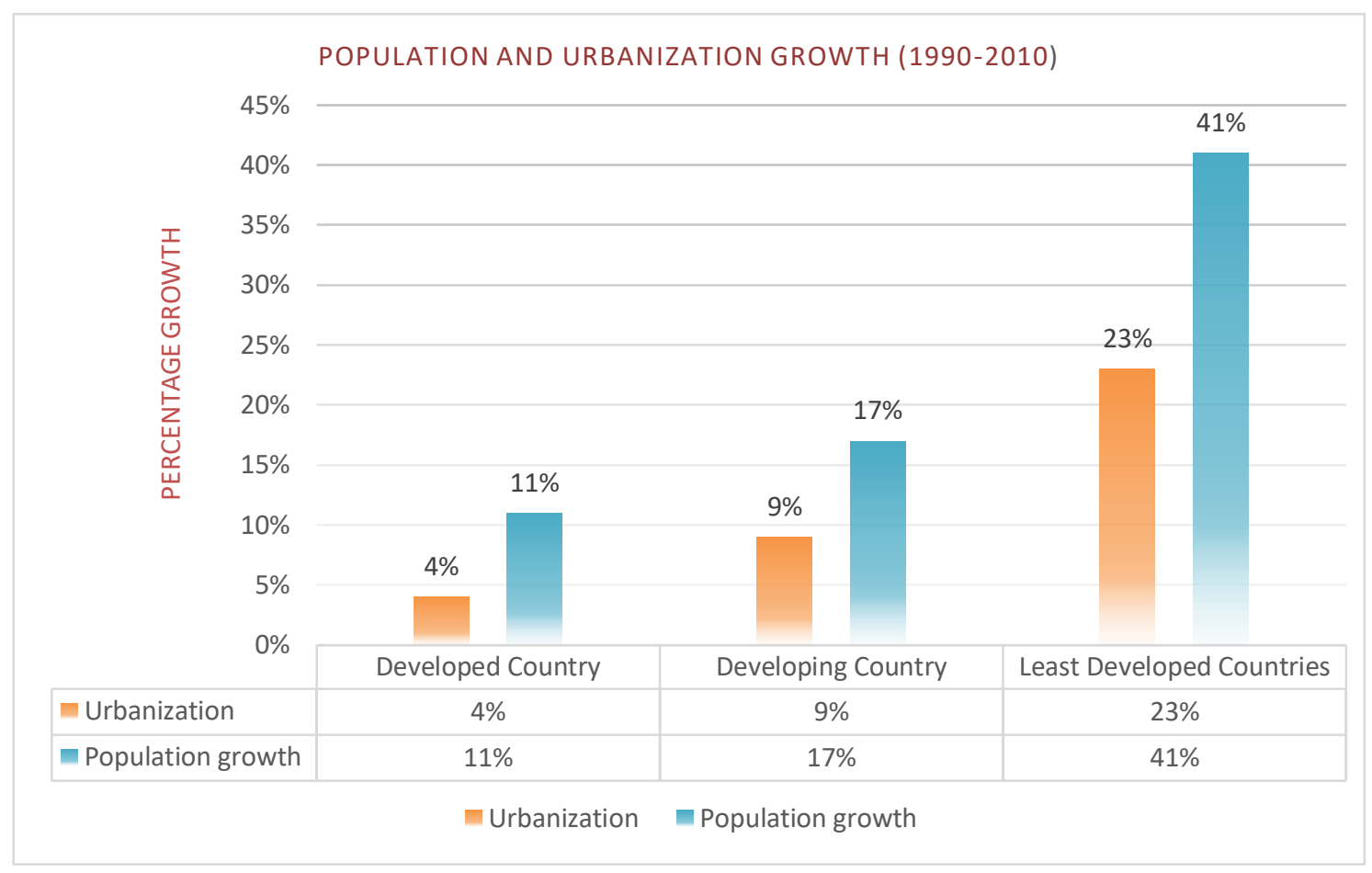

Chart 1: Population and Urbanization growth (1990-2010). (From Khatib, A. Imad, Municipal Solid Waste Management in Developing Countries: Future Challenges and Possible Opportunities.

The reality is that the growth in urbanization does not always mean improving situations, including sectors developments. In the recently published 2010 human development report (UNDP, 2010), indicators that describe the accessibility to water and sanitations in developing and least developed countries are not encouraging at all. It is found that an average of about $45 \%$ of countries' populations are lacking proper sanitation infrastructures, and an average of $20 \%$ are lacking proper accessibility to water. In addition, the report showed that the percentage of populations living on degraded land is increasing to an average that exceeds $15 \%$. Hence, the consequence of the unplanned urbanization growth will definitely lead to huge problems on governments especially for meeting the increasing demand for proper and healthy municipal services. The growth will result in increase in the quantity and complexity of the generated wastes and overburdens, including solid wastes, and in particular municipal solid waste (MSW). MSW includes materials discarded for disposal by households, including single and multifamily residences, and industrial waste from canteens / restaurants and hotels and motels and from commercial and industrial entities essentially the same as waste normally generated by households and collected and disposed by normal municipal solid waste collection services. Such MSW is considered a problem that having impacts on the environment and the public health if not properly managed.

\section{SOLID WASTE IN HISTORY}

Globally, solid waste is one of the subjects of greatest concern for the environment. Historically, the environment has been considered a sink for all the waste produced by human activities since the beginning of civilization. The suitable environment, in which the human race resides, along with the flora and fauna, is a gift of nature, formed through different phenomenal natural activities. When humans abandoned nomadic life at around 10,000 BC, they began to live in communities, resulting in the mass production of solid waste. Waste piled up and people wallowed in the offal, a characteristic that seems to be unique to the human animal. There were exceptions, of course. In the Indus valley, the city of Mohenjo-Daro had houses with rubbish chutes and probably had waste collection systems. Other towns on the Indian subcontinent like Harappa and Punjab had toilets and drains and by 2100 $\mathrm{BC}$, the cities on the island of Crete had trunk sewers connecting homes. The sanitary laws written by Moses in 1600 BC still survive in part. By 800 BC, old Jerusalem had sewers and a primitive water supply. By $200 \mathrm{BC}$, the cities in China had sanitary police whose job was to enforce waste disposal laws. But for the most part, people in cities lived among waste and squalor. Only when the social discards became dangerous, for defence was action taken. In Athens, in $500 \mathrm{BC}$, a law was passed to require all waste material to be deposited more than a mile out town because the piles of rubbish next to the city walls provided an opportunity for invaders to scale up and over the walls. Rome had similar problems and eventually developed a waste collection program in 14AD (Worrel and Vesilind, 2012). 
International Journal of Engineering Applied Sciences and Technology, 2020

Vol. 5, Issue 7, ISSN No. 2455-2143, Pages 157-173

Published Online November 2020 in IJEAST (http://www.ijeast.com)

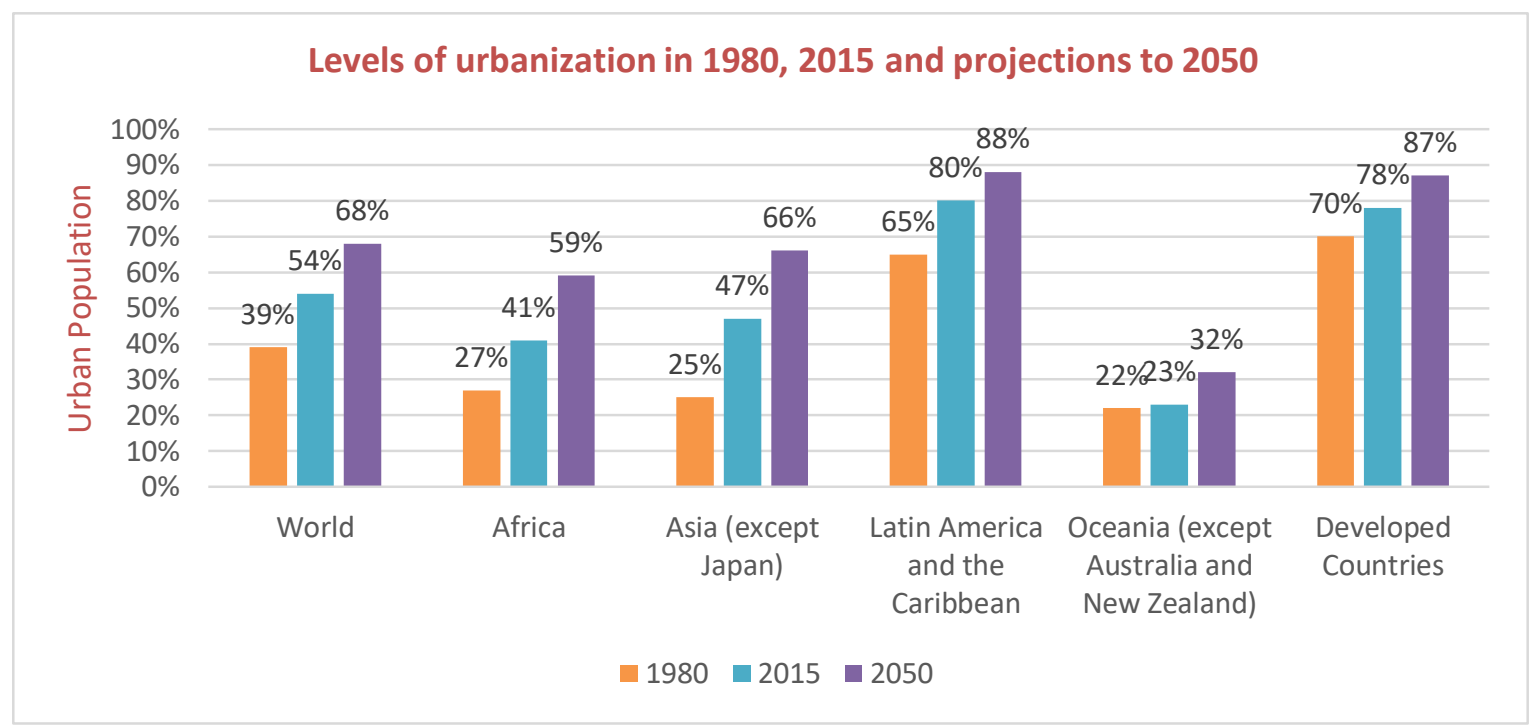

Chart 2: Source: United Nations (2018d), World Urbanization Prospects: The 2018 Revision

For the first time in history, more people now live in urban than in rural areas. The proportion of the world population living in cities has increased rapidly. Over the next three decades, global population growth is expected to take place almost exclusively in the world's cities and towns, in part due to migration from rural areas. In developed countries and those of Latin America and the Caribbean, a large proportion of the population already resides in urban areas. Africa and Asia are still largely rural but are urbanizing faster than other regions. In all regions, the speed of urbanization is slower now than in past decades, largely because many countries are already highly urbanized. The rate of urban population growth is also declining, and is expected to continue falling until 2050, although it is still very high in Africa. Nevertheless, the total number of people living in cities is expected to grow substantially, from approximately 4.4 billion in 2020 to 6.7 billion in 2050 (United Nations, 2018d). Africa and Asia alone are projected to account for an increase of 2 billion people living in urban areas by 2050 . In contrast, the number of people living in rural areas is estimated to decline from 3.4 billion in 2015 to 3.1 billion in 2050. Migration from rural to urban areas has historically played a key role in the rapid growth of cities. Together with the reclassification of rural into urban communities, migration continues to be an important component of urban growth. However, natural population growth, the difference between births and deaths currently makes a larger contribution to the growth of cities than internal migration in the majority of developing countries (United Nations, 2018d).

Solid waste needs to be characterized by sources, generation rates, types of wastes produced, and composition in order to monitor and control prevailing waste management systems while improving the existing system. These data will help to make financial, regulatory and institutional decisions. But population explosion and invention of new materials have kept the quantities and characteristics changing every day. As per the conservative estimation done by the World Bank in 1999, the municipal solid waste (MSW) from urban areas of Asia would raise from 760,000 tonnes/day in 1999 to 1.8 million tonnes/day in 2025. With the increasing income in the countries of Asia, the solid waste management would be more challenging in the coming days in the continent. New products wrapped with new packaging materials, new living standards and expectancy, change in income and life style practiced by the affluent people have increased global waste quantity (Chandrappa and Das, 2012). 
International Journal of Engineering Applied Sciences and Technology, 2020

Vol. 5, Issue 7, ISSN No. 2455-2143, Pages 157-173

Published Online November 2020 in IJEAST (http://www.ijeast.com)

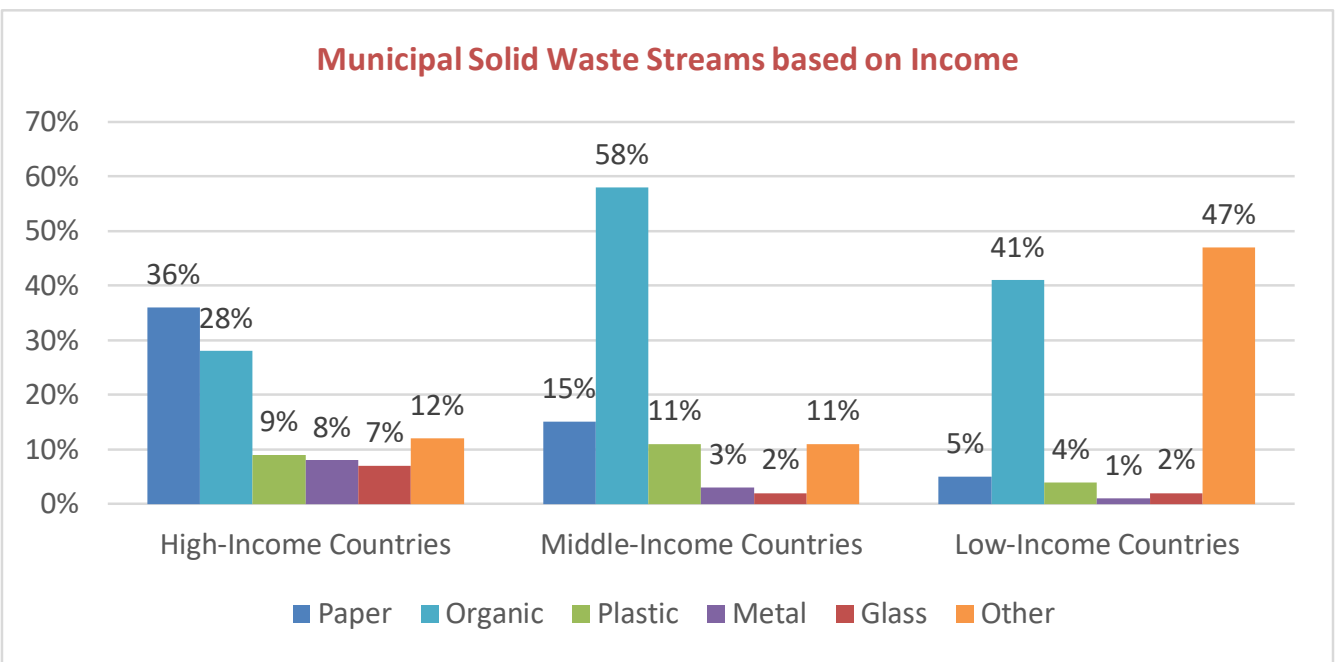

Chart 3: Composition of Municipal Solid Waste Streams based on Income (UNDESA, 2010)

Municipal Solid Waste (MSW) includes wastes produced from commercial, domestic, industrial, institutional, demolition, construction and municipal services. But the data pertaining to MSW vary greatly among the waste studies. Usually waste management decisions are based on house-hold waste, which constitutes a small portion of the total waste stream. Further, industries and commercial activity hide the information to avoid statutory obligations. Industries often struggle to increase profit and reduce waste. Manufacturing sector generates MSW from offices and canteens as well as industrial wastes from manufacturing activities some of which are hazardous. Small workshops spread across the urban/rural area as well as along the highways generate both municipal and hazardous waste which requires treatment and disposal differentially. Healthcare establishments like hospitals, clinic, veterinary institutions, blood banks, pathological laboratories, diagnostic centres, artificial insemination centres, clinical research centres have multiplied in all countries over the years to generate MSW as well infectious/chemical/radioactive and sharps.

Construction and demolition sites also produce some MSW like food and office wastes, along with construction and demolition wastes. Households produce construction and demolition wastes during repairs and refurbishment. Residences and commercials activities also generate household hazardous wastes like pesticides, batteries, and discarded medicines. Some cities in the developed nations have waste management systems for each of these categories like hazardous, MSW, infectious separately. Activities like agricultural, mining and quarrying will generate MSW and non-municipal waste streams. Treatment of waste water produces a semisolid, nutrient rich sludge which is often referred as biosolids. It can be recycled and used to improve soil nutrition of crop land. Biosolids contain about 93-98\% water. The municipal solid waste characteristics and quantity is a function of the lifestyle and living standard of the region's inhabitants.

Residential Waste composes of decomposable food waste, packaging material comprising paper, plastic, old cloth, hazardous waste like old battery, nail polish bottles, insecticides, after shaving lotion, bottle, and biomedical waste like sanitary napkin. Waste quantity varies depending on income and development of the country.

1. Commercial: Waste composes of decomposable food waste, packaging material comprising paper, plastic, hazardous waste includes used batteries, chemical containers. Waste quantity varies depending on the activities and turnover.

2. Gardens: Waste predominantly composes of garden trimming and leaves. Hazardous chemicals include packaging material of agro-chemicals. The waste cold includes packaging material like cover used for chips, ice cream cups etc.

3. Industrial: Waste depends of product of the industry. Industrial waste comprises highly hazardous chemicals to non-hazardous packaging material. Quantity of waste depends on quantity and type of product manufactured.

4. Agriculture and Rural: Waste mainly comprises of rotten vegetable, fruits, leaves and other plant parts. Hazardous chemicals include packaging material of agrochemicals. Most of the waste will be used within the same farm/estate hence quantity is negligible.

5. Construction and Demolition (C\&D): Waste mainly comprises of concrete, brick pieces, soil, wood, metals, and other debris. Recyclables material like steel and other metals are recovered by construction/demolition agencies. The quantity depends on size of construction/demolition and construction technology.

6. Transportation: This category can be included as subcategory of commercial activity. While developed countries do not generate waste along roads and railway tracks. But people throw waste all along roads and railway tracks in developing world. The quantity of solid waste besides railway track depends on the traffic and number of passengers travelled.

7. Water and Waste water Treatment Plants: These plants generate hazardous and non-hazardous sledges and packing material. Quantity of solid 
waste depends on the quality/quantity of water/waste water treated.

8. Beaches and Recreation areas: This category mainly contains litters of food wrappers made up of paper, plastic, metal and glass. Quantity of waste depends on number of visitors.

9. Slums: Slum people generate least quantity among all urban sectors. Since the dwellers are poor, they make use of the materials available to maximum extent and sell recyclable fraction. Many of the dwellers depend on waste for livelihood. The waste mainly contains ash and decries which does not have recyclable value.
10. Fruit and Vegetable Markets: Fruit and vegetable market prominently contains decomposable waste like rotten and damaged fruits and vegetables. A small percentage of packaging like cardboard, plastic and paper may be present in the waste. Citrus and other sour fruits like pine apple may add to acidity of the waste.

11. Slaughter Houses: Waste mainly comprises of hide, hair, fur, undigested and digested food, bones, and meat. The waste is highly putrescible in nature and likely to have pathogens that could cause zoonoses.

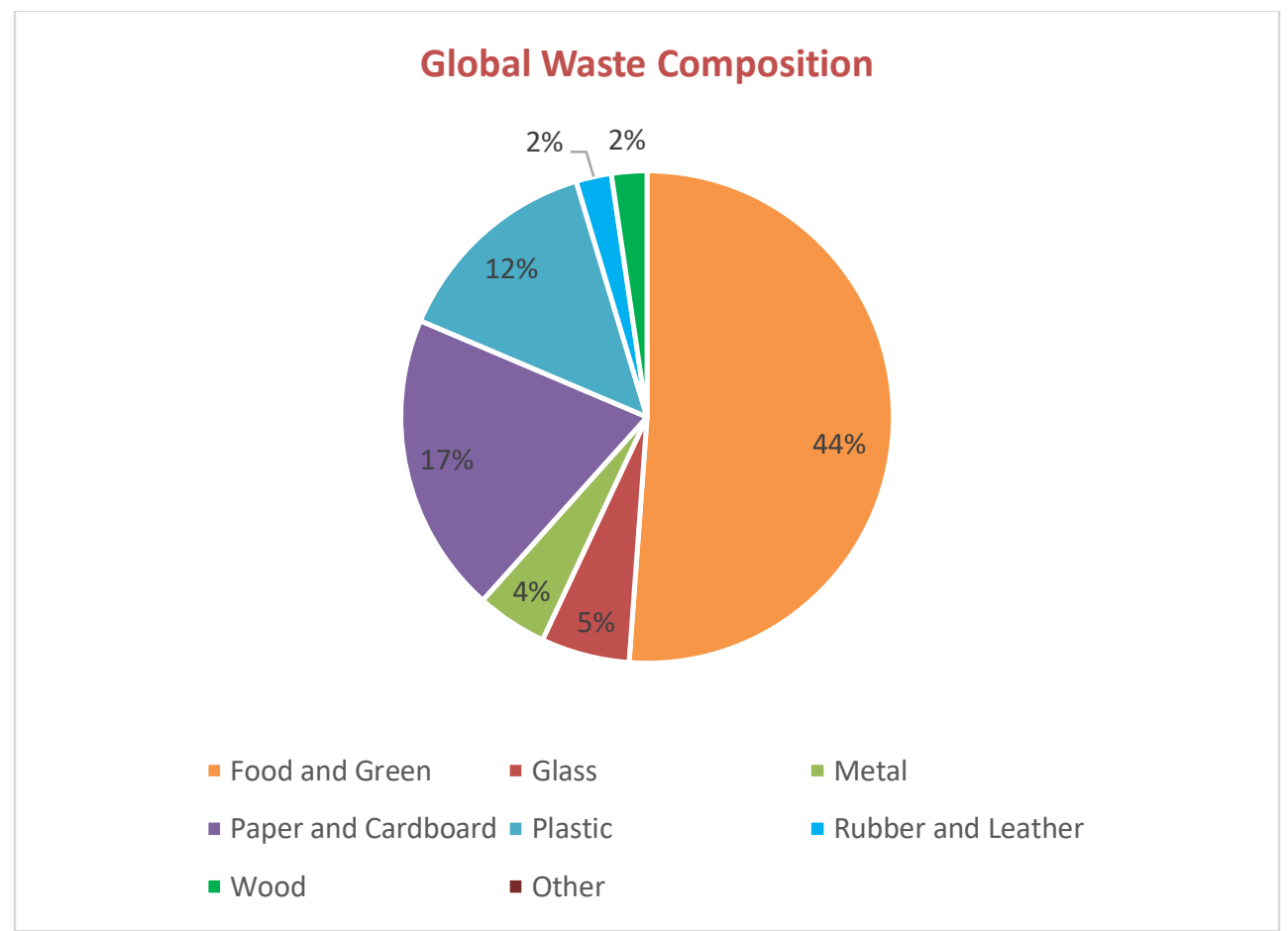

Chart 4: Source: What a Waste 2.0: A Global Snapshot of Solid Waste Management to 2050

In one study that was conducted to estimate the possibility of diverting waste from the landfill through prevention and recycling, $\mathbf{4 3}$ different categories were established.

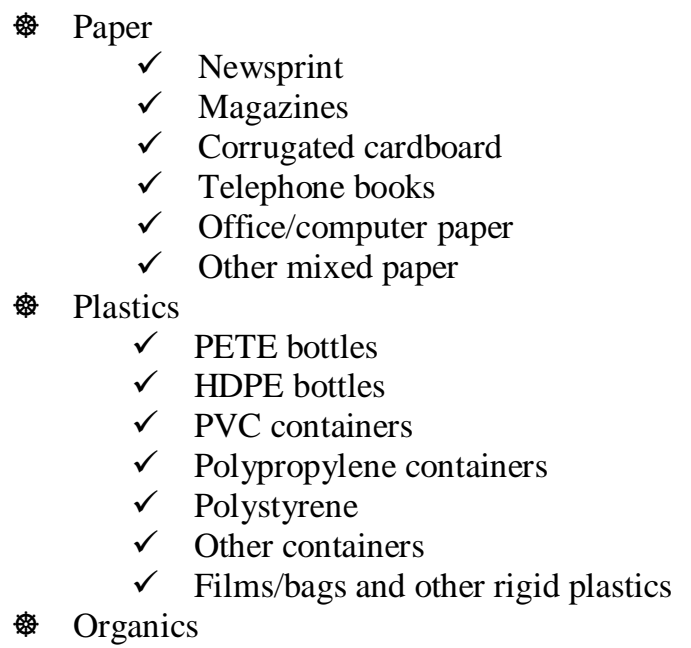

$\checkmark$ Food waste

$\checkmark$ Textiles/rubber/leather

$\checkmark$ Fines (unidentifiable small organic particles)

$\checkmark$ Other organics

Ferrous materials

$\checkmark$ Ferrous / bimetal cans

$\checkmark$ Empty aerosols

$\checkmark$ Other ferrous metals

Nonferrous metals

$\checkmark$ Aluminium cans

$\checkmark$ Other nonferrous metals

Electronic components

$\checkmark \quad$ Parts and materials from computers

$\checkmark$ Printers

$\checkmark$ Copy machines

Glass
$\checkmark$ Clear
$\checkmark$ Green
$\checkmark$ Brown
$\checkmark$ Other glass 
International Journal of Engineering Applied Sciences and Technology, 2020

Vol. 5, Issue 7, ISSN No. 2455-2143, Pages 157-173

Published Online November 2020 in IJEAST (http://www.ijeast.com)

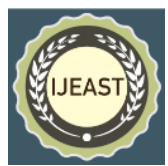

Wood

$\checkmark$ Lumber

$\checkmark$ Pallets

$\checkmark$ Other wood

Inerts

$\checkmark$ Asphalt roofing materials

$\checkmark$ Concrete/brick/rock

$\checkmark$ Sheet rock

$\checkmark \quad$ Ceiling tiles

$\checkmark$ Dirt/dust/ash and other inerts

Yard waste

$\checkmark$ Grass clippings

$\checkmark$ Leaves

$\checkmark$ Trimmings

Hazardous materials

$\checkmark \quad$ Lead acid batteries

$\checkmark$ Other batteries

$\checkmark$ Other hazardous wastes

In addition to the usual residential and commercial solid waste, municipal engineers have to deal with special or unusual waste. These wastes may include items such as inert material (materials that do not degrade, such as rocks), agriculture waste, sludge from both water and waste water treatment facilities, tires, household hazardous waste and medical waste. Each of these special wastes must be managed in a way that protects human health and welfare and complies with applicable regulations.

Within the available data, waste from high human development show higher fraction of non-degradable waste comparable to medium human development. The reason for such fraction is due to high spending of rich countries on packaging material, absence of rag picking, and low number of scrap dealers, etc. The developing countries use newspaper and other unsoiled paper for packaging including food item. It is not uncommon to see restaurants and road side merchants packing food items, fruits and vegetables in newspapers and covers made-up of newspapers. The number of old scrap merchants in India is high and house and offices sell old paper to these dealers. These dealers in turn sell them to recyclers and other end users.

The huge number of rag pickers is one of the reasons for very low amounts of paper, plastic, glass and metals in the wastes. Rag pickers can be seen at residential, commercial, industrial and waste dump areas trying to pick all recyclable fractions of waste. The people in the developed countries are expected to have higher income jobs and hence there is a general absence of rag picking. The waste papers and old newspapers will be put into trash instead of storing at a point of generation for selling to scrap dealers. On the contrary the developing countries will generate high industrial waste due to the non-adoption of waste minimisation technology and weak environmental legislations compared to the developed countries.

\section{III. e-WASTE}

Waste electrical and electronic equipment (WEEE), popularly known as 'e-waste', comes from a broad range of electronic products such as computers, televisions, or video games, as well as all kinds of electrical equipment, often divided into large equipment (washing machines, airconditioners, freezers etc.) and small equipment (hairdryers, electric toothbrushes, vacuum cleaners etc.). This is the fastest-growing waste stream all around the world due to increased consumer demand, perceived obsolesce, and rapid changes in technology and inventions of new electronic devices. The situation is compounded by the short lifespans of certain products and products not being designed with recycling in mind. A 2015 report by the United Nations University (UNU) estimated that 41.8 million tonnes (Mt) of e-waste was generated in 2014 , almost $25 \%$ more than the 2010 figure of $33.8 \mathrm{Mt}$.

\section{Composition of e-Waste}

The composition of WEEE/e-waste is very diverse, as electrical and electronic equipment encompasses such a broad range of categories. In general, it is characterized by containing a combination of metals, plastics, chemicals, glass and other substances. Among the substances of particular interest are a very wide range of metals including rare earth metals like lanthanum, cerium, praseodymium, neodymium, gadolinium and dysprosium; precious metals such as gold, silver and palladium; or other metals such as copper, aluminium or iron, which have a high intrinsic value. However, even though 'critical materials' are scarce, they have recycling rates lower than $1 \%$, which represents a threat to resource security over the long term. Others substances which are hazardous or potentially hazardous, such as lead-containing glass, plastics treated with brominated flame retardants or ozone-depleting substances such as CFCs, are of concern due to the potential health and environmental risks they might pose.

\section{Initiatives to control e-waste}

The Basel Convention has been addressing e-waste issues since 2002, when the Convention's Mobile Phone Partnership Initiative (MPPI) was adopted. The overall objective of the MPPI was to promote the objectives of the Basel Convention in the areas of environmentally sound management of end-of-life mobile phones, prevention of illegal traffic to developing countries and building capacity around the globe to better manage e-waste. Under the MPPI, five technical guidelines were developed, including awareness raising and design considerations, collection of used and end-of-life mobile phones, transboundary movement of collected mobile phones, refurbishment of used mobile phones and material recovery/recycling of endof-life mobile phones. The guidelines were tested in a facility type environment and then revised. In 2006, the Nairobi Declaration on the Environmentally Sound Management of Electrical and Electronic Waste was adopted under the Convention, calling for more structured and enhanced efforts towards achieving global solutions to manage e-waste problems and encouraging Parties to develop further partnerships targeting e-waste. More recently, the Partnership for Action on Computing Equipment (PACE) was developed as a muti-stakeholder public-private partnership that provides a forum for representatives of manufacturers, recyclers, international organizations, associations, academia, environmental groups 
and governments to tackle environmentally sound refurbishment, repair, material recovery, recycling and disposal of used and end-of-life computing equipment. PACE has produced various kinds of materials, including guidelines on environmentally sound testing, refurbishment and recycling of used computing equipment; guidelines on environmentally sound material recovery and recycling of end-of-life computing equipment; and a report on strategies, actions and incentives to promote environmentally sound management of used and end-of-life computing equipment.

\section{Solid Waste Problem in Doda region of Jammu \& Kashmir, India}

Solid waste problem in Doda is increasing rapidly at a very fast pace. With thousands of people migrating to the urban areas of Doda every year, the problem of solid waste in the region has increased manifold. Improper management of solid waste and sewage sludge can pose serious issues in the near future. The limited carrying capacity of urban areas of Doda region will soon reach its utmost limit in a few years. Lack of adequate hygiene and sanitation in the urban areas of Doda region can result in serious consequences for the inhabitants of the region. It can lead to public health crisis and it would be no surprise that it can also lead to COVID-19 like pandemics and epidemics in the near future if the problem of solid waste is not addressed well in time and allowed to become rampant.

The plague epidemic in Surat is one example of a public health crisis that stimulated new initiatives to collect the waste and clean up the city, now known as one of the cleanest in India. Uncollected solid waste blocking drains caused a major flood, leading to an outbreak of a plague like disease in Surat, India, in 1994. The disease caused panic countrywide, and while the citizens blamed the municipality, the public authorities, in turn, blamed the citizens for their lack of civic sense. Over 1000 plague suspected patients were reported, with the final death toll of 56 people. The city incurred a daily loss of 516 million Indian rupees during the plague period and a total loss amounting to 12 billion rupees. This was a high price to pay for negligence in the area of solid waste management.

Alarmed at the situation, the Surat Municipal Corporation undertook a stringent

programme of cleaning the city. Within a year after the plague, the level of daily solid waste collection increased from 30 to $93 \%$ and $95 \%$ of streets are cleaned daily. Market areas, major roads and litter-prone spots are cleaned twice a day. Surat is now identified as one of the cleanest cities in the region.

\section{Potential for a COVID-19 like Pandemic}

What started from the wet markets of Wuhan in China is no less than an important lesson for all the mankind that how a microscopic novel virus like SARS-CoV-2 can unleash a pandemic all over the world and can change every aspect of our lives. Places with poor hygiene and sanitation are the breeding grounds for all such deadly and lethal disease causing agents. Accumulated solid waste at any place is the perfect ground where all such agents of epidemic and pandemic level potential thrive profusely.
Therefore, solid waste management should be done in a proper manner and ample hygiene and sanitation should be maintained to avoid such a holocaust in future.

\section{Initiatives to tackle solid waste problem in India}

Effective October 2, 2019, the Indian government announced a ban on six plastic items of daily convenience with their thickness below 50 microns. These items include plastic bags, cups, plates, small bottles (below $200 \mathrm{ml}$ capacity), straws and certain types of sachets. Since then, the government set up an expert committee involving raw material manufacturers, scrap processors, exporters and importers to frame an industry-friendly policy. The ban on the usage of single-use plastics, however, has prompted the usage of alternatives for packaging including clothes, paper, glass etc.

Three months after officially banning six varieties of single use plastic materials, the government is considering fixing a minimum thickness of 125 microns for polyethylene bags and other products of convenience packaging. Currently, plastic items with thickness below 50 microns are banned in the country. Moreover, government is also sensitizing people about the detrimental effects of improper solid waste management and the threats it can pose to human lives and to the society as a whole. Government is also running campaigns to aware the people that if there would be improper disposal of solid waste then it can jeopardize and drastically impact the life of every human being.

Waste management in India falls under the purview of the Union Ministry of Environment, Forests and Climate Change (MoEF \& CC). In 2016, this ministry released the Solid Wastage Management (SWM) Rules, 2016, these rules replaced the Municipal Solid Wastages (Management and Handling) Rules, 2000 which had been in place for 16 years. This national policy is notable in that it has acknowledged and included the informal sector (waste pickers) into the waste management process for the first time. Urban India (about 377 million people) generates 62 million tonnes of municipal solid waste (MSW) each year. Of this about 43 million tonnes $(70 \%)$ is collected and 11.9 million tonnes $(20 \%)$ is treated. About 31 million tonnes $(50 \%)$ is dumped in landfill sites. With changing consumption patterns and rapid economic growth, it is estimated that urban municipal solid waste generation will increase to 165 million tonnes in 2030. These rules are the sixth category of waste management rules brought out by the ministry, as it has earlier notified plastic, e-waste, biomedical, hazardous and construction and demolition waste management rules. The new rules have mandated the source segregation of waste in order to channelize the waste to wealth by recovery, reuse and recycle. Waste generators would now have to now segregate waste into three streams- Biodegradables, Dry (Plastic, Paper, metal, Wood, etc.) and Domestic Hazardous waste (diapers, napkins, mosquito repellents, cleaning agents etc.) before handing it over to the collector.

\section{District Hospital Doda, Jammu and Kashmir}

The pictures (Fig. 1, 2 and 3) are of the premises and Vicinity of District Hospital Doda. As is clearly seen in 
the pictures, huge amounts of un-attended Bio-medical waste is lying in the premises and vicinity of the hospital. It contains disposed off single use syringes, cannulas, catheters, saline bottles, surgical instruments, gloves, polythenes, plasters, bandages, sanitary pads, diapers, bloodsoaked bandages, cotton, and clothes, human tissue removed during surgery and afterbirths et cetera.

This poses a huge environmental risk and is also detrimental to the health of the patients as the hospital premises should be completely clean, hygienic and sanitised.

This unattended Bio-medical waste can also result in the spreading of many diseases and is a point of great concern during the Covid-19 pandemic.

Moreover, many bovine animals and stray dogs frequently visit there in search of food. It can cause serious problems in them too. The stray dogs are often seen visiting these heaps of Bio-medical waste in search of food and animal tissue. They eat discarded human tissue, afterbirths, human excreta et cetera. It can cause many serious diseases in them too.

They can also spread those diseases in other dogs of the community too which can become a serious threat and handicap for the society as it can result in zoonosis due to eating contaminated human tissues.

Many pictures show the reckless dumping of solid waste over a wide area in front of the District Hospital
Doda. Moreover, a wrecked and discarded mini bus (Fig. 4) is also lying there. The bus is being used as a trash bin to dump waste by the local people. Such a cover of waste material over a large area harbours a lot of disease-causing agents. Many a times snakes have been spotted there as they usually hide in garbage and if a person or an animal happens to pass that very place, s/he can become a victim of a lethal snake bite which can result in the death of that very person or animal. This cover of solid waste over a large area poses a great environmental risk and contaminates the environment.

Many a times, there have been instances of fire in the heaped-up solid waste lying there which results in air pollution and can also spread to nearby houses as there are numerous houses and properties in the close vicinity of the dumping site.

Stray dogs and bovine animals visiting these sites in search of food remains a great cause of concern for the society as it can prove harmful for their health and can also result in zoonoses.

Birds have also been seen visiting these sites for food which can pose a great risk to the local biodiversity as it can cause many serious diseases in them too because these sites are teeming with numerous harmful bacteria and viruses.

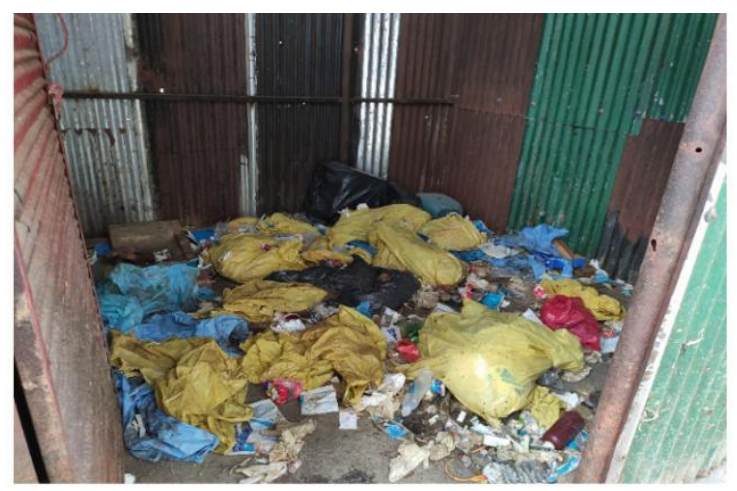

Fig. 1a

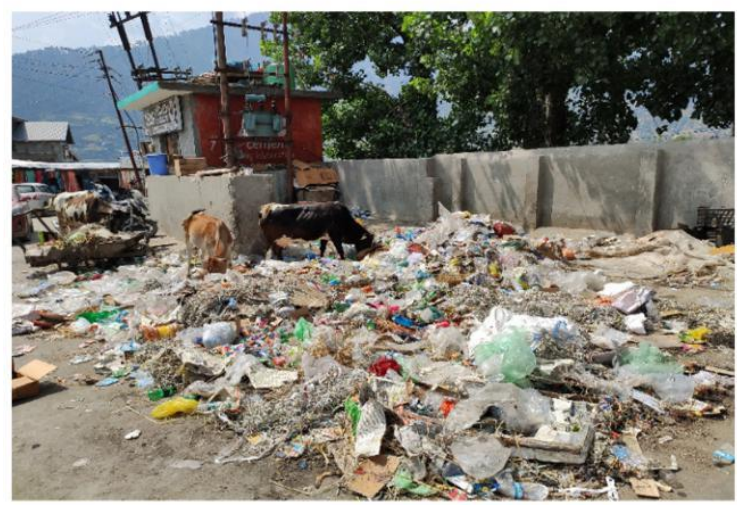

Fig. 1c

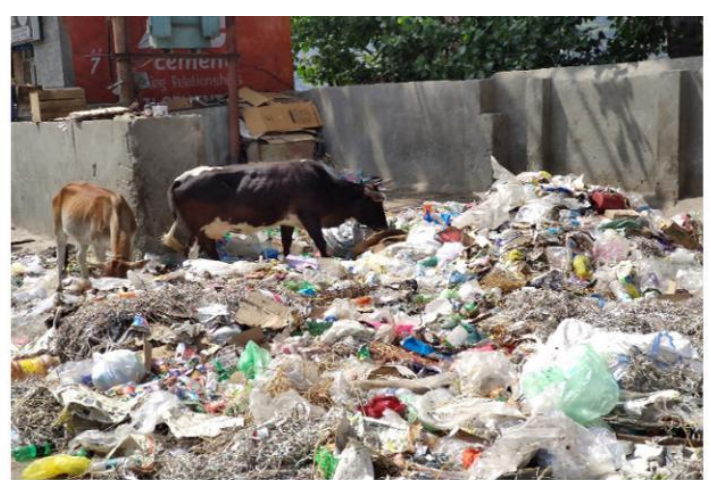

Fig. 1b

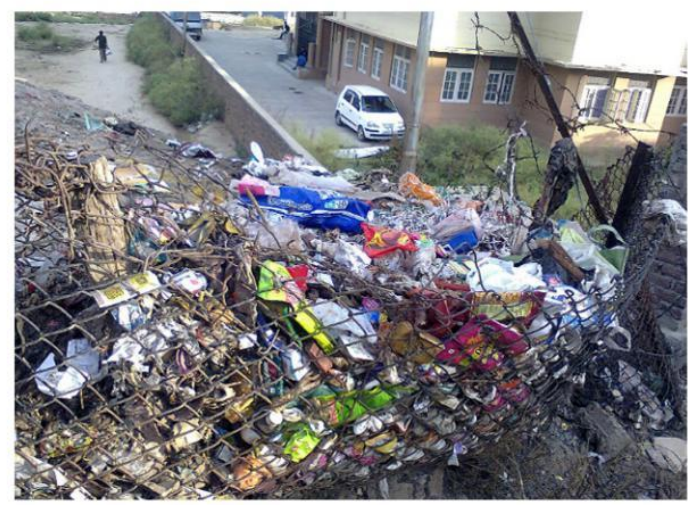

Fig. 1d

Fig. 1: Bio-medical Waste in premises and vicinity of District Hospital Doda, Jammu \& Kashmir 
International Journal of Engineering Applied Sciences and Technology, 2020

Vol. 5, Issue 7, ISSN No. 2455-2143, Pages 157-173

Published Online November 2020 in IJEAST (http://www.ijeast.com)

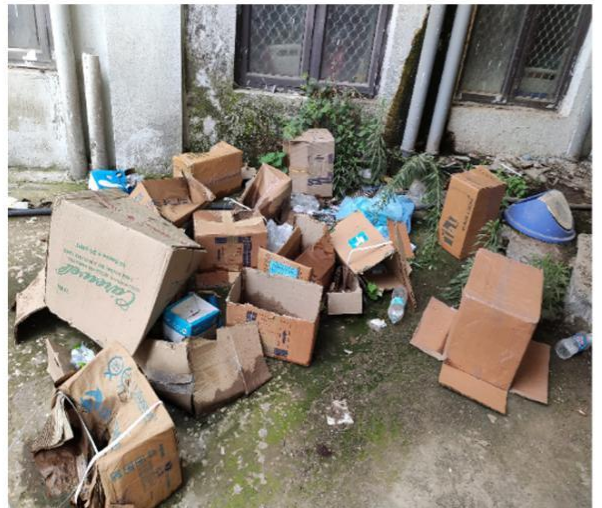

Fig. 2a

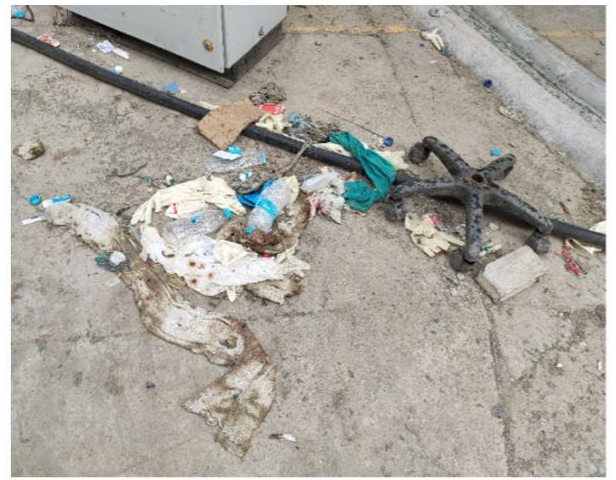

Fig. 2c

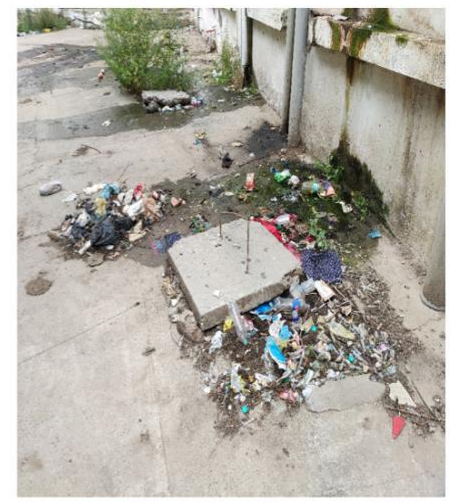

Fig. 2b

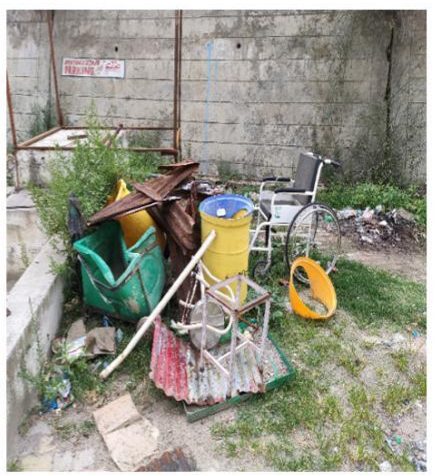

Fig. 2d

Fig. 2: Bio-medical Waste in premises and vicinity of District Hospital Doda, Jammu \& Kashmir

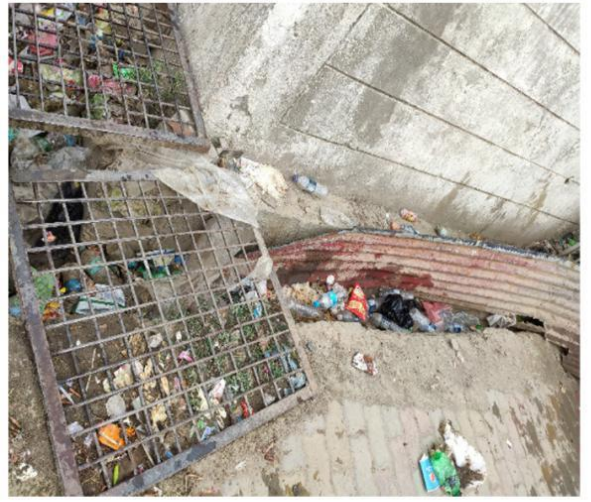

Fig. 3a

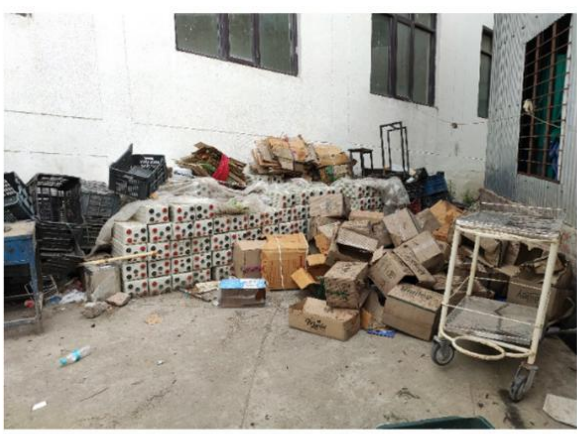

Fig. 3c

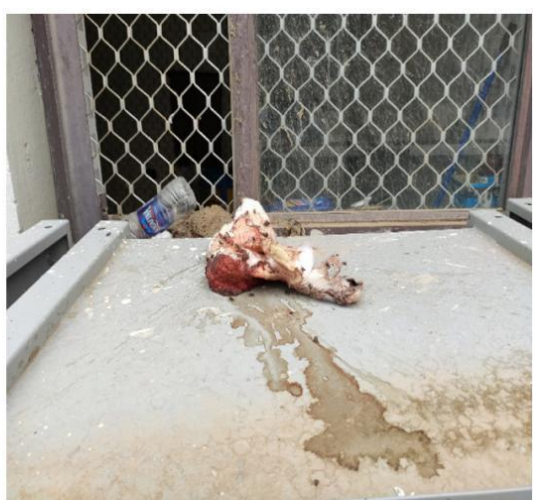

Fig. 3b

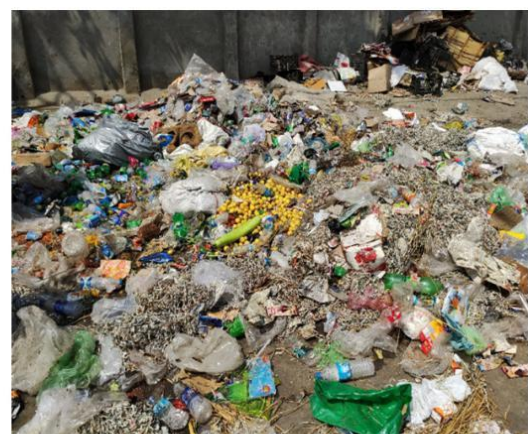

Fig. 3d

Fig. 3: Bio-medical Waste in premises and vicinity of District Hospital Doda, Jammu \& Kashmir 


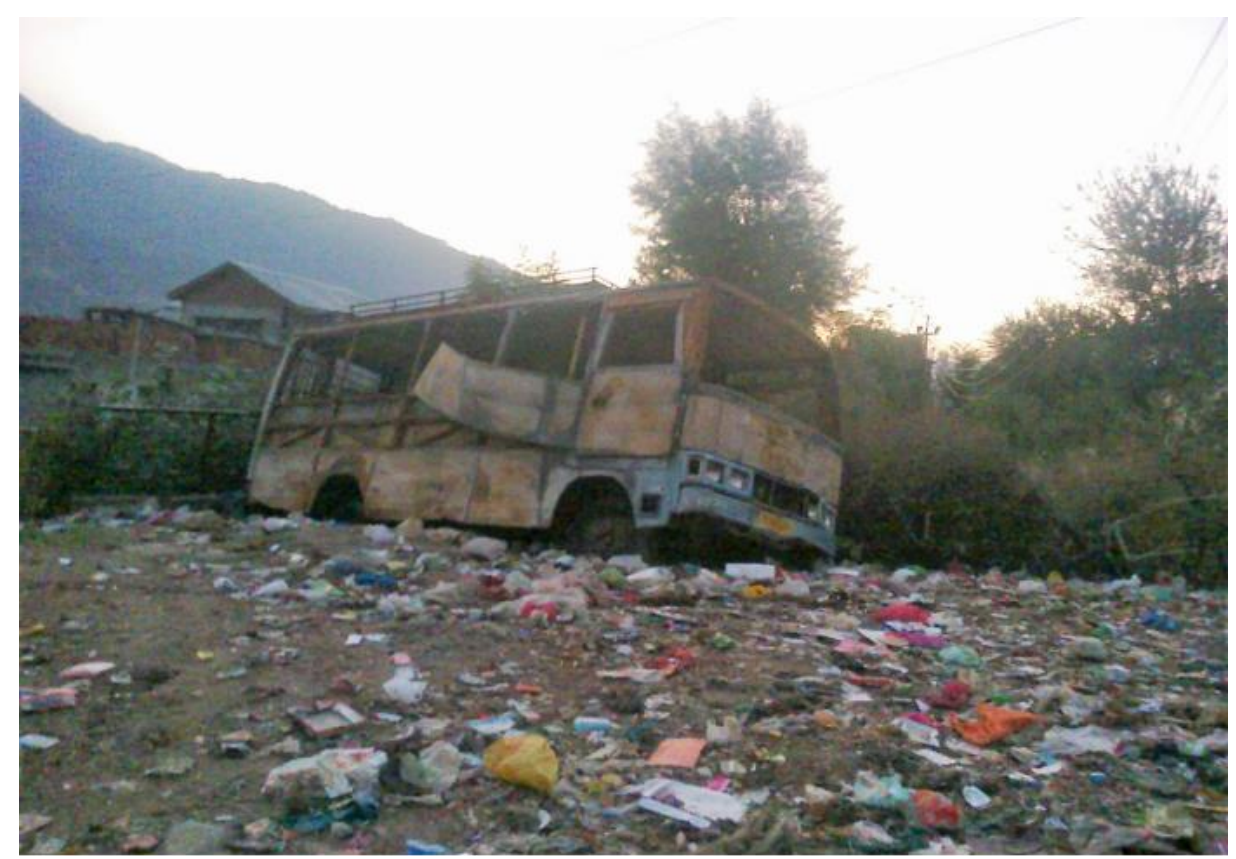

Fig. 4: Wrecked and Damaged Minibus being used as Trash/Dustbin

\section{Tondwah, Doda Jammu and Kashmir}

The picture (Fig. 5, $6 \&$ 7) are of Circular Road in Tondwah area of Doda. As is clearly seen in the pictures, a huge heap of refuse and waste is lying there with many bovine and stray animals and donkeys present at the site searching for food. Sometimes, the solid waste accumulates to so much extent that it spreads on the road completely causing immense inconvenience to school children, local pedestrians and even to vehicles passing by the road. Moreover, many bovine and stray animals also come to these waste dumping sites to quest for food. The stale and spoiled food dumped there can make these domestic animals ill and can afflict them quite seriously. It can also affect their milk producing ability and the quality of their milk. This can also reduce their milk's nutritive value. Furthermore, sometimes people dump such things which on consumption by cattle can prove lethal for them such as needles, chemicals \& poisonous substances. A great precedent to this is the "Mad Cow Disease" which caused the sudden death of several cows in Europe in the 20th century. All these things pose a great environmental risk and also for the society.
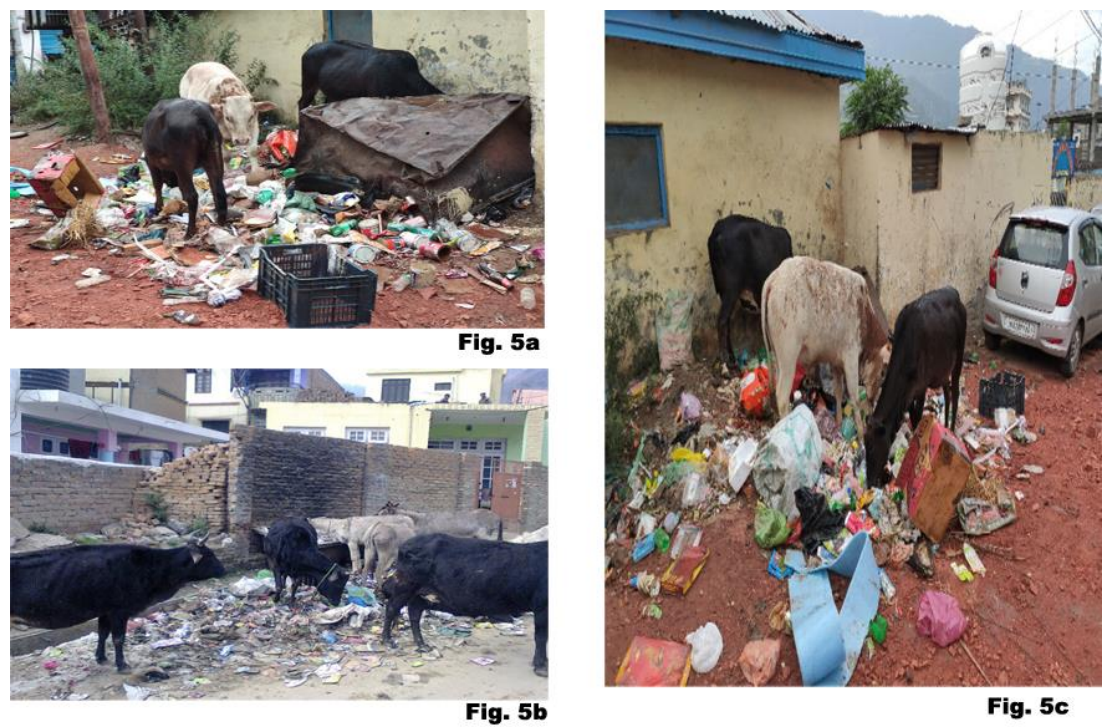

Fig.6: Huge Heap of Refuse and waste in Tondwah Doda 


\section{International Journal of Engineering Applied Sciences and Technology, 2020 \\ Vol. 5, Issue 7, ISSN No. 2455-2143, Pages 157-173 \\ Published Online November 2020 in IJEAST (http://www.ijeast.com)}

The pictures (Fig. 6 ) are of a construction site in Tondwah area of Doda. This construction site is located adjacent to the District Hospital Doda. As is clearly seen in the pictures, there are huge heaps of soil and other construction waste which is a result of large-scale machine excavation at the construction site. This has resulted in the unearthing of large amounts of soil and huge boulders as is seen in the pictures. This causes a huge damage to the local flora plant diversity of the area. During periods of heavy downpour in the area, the accumulated soil gets washed away on the roads which causes great trouble to the local people because the roads gets completely muddy. This has also resulted in road accidents many times in the area. This land pollution is a cause of great concern and causes largescale environmental degradation.

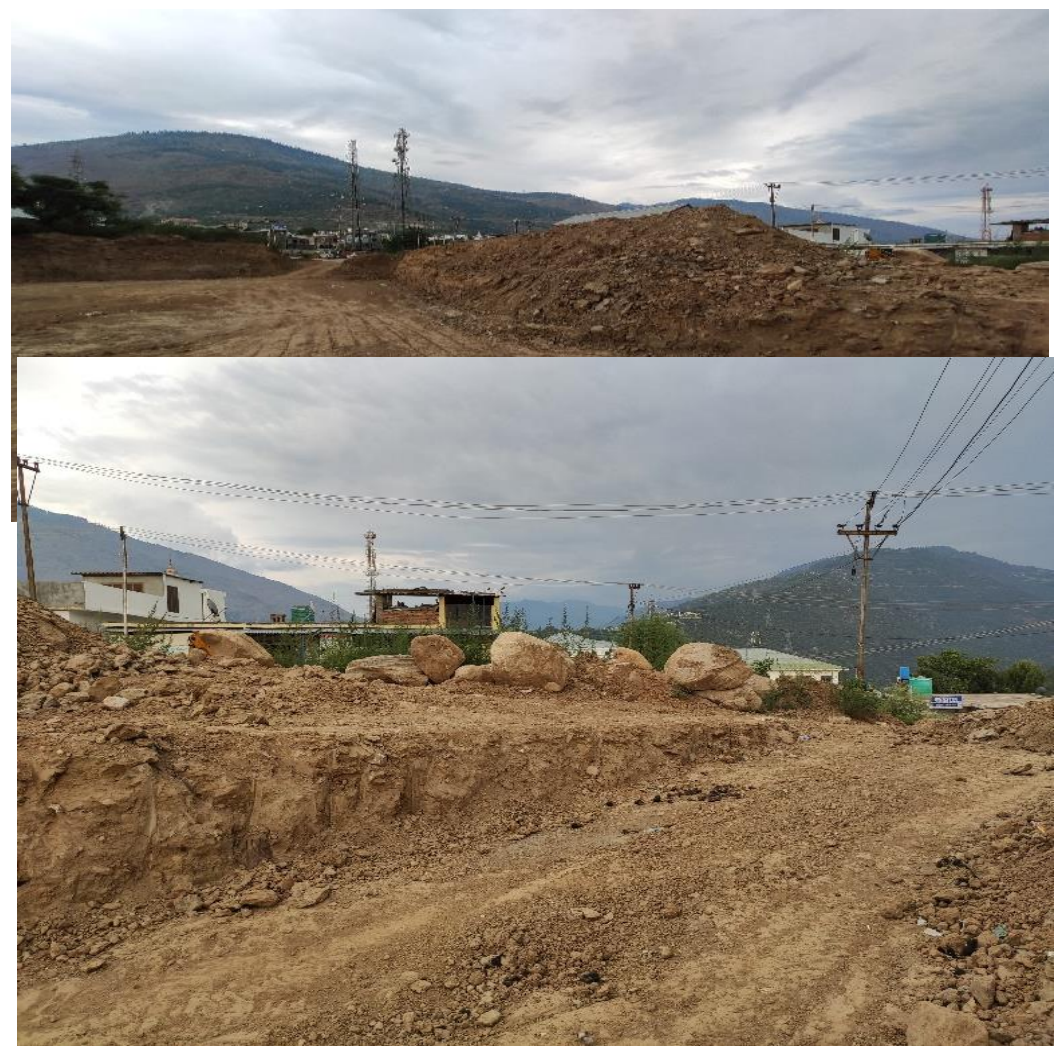

\section{Nagri Area of Doda, Jammu and Kashmir}

The pictures (Fig. 7) are of Nagri area of Doda. As is clearly seen in the pictures, there is huge amounts of glass and solid waste lying on the road. The road is in front of J\&K Bank Branch Nagri which has been made a dumping site by the local people. As is clearly seen in the pictures, large uprooted tree stumps are lying beside the road and open drains teeming with solid waste and sewage sludge. This causes great inconvenience to the local people and school children. Many a times, there have been many accidents on this road owing to this unattended solid waste and tree stumps on the road. During periods of rain, the drains teeming with sewage waste often overflow and scatter the huge sewage sludge on the adjacent road. This makes the road stinky and dirty and unfit for use by the local people. Moreover, it also spreads various diseases and infections as numerous disease-causing micro-organisms harbour in these conditions. Furthermore, it also destroys the aesthetics of the area. This isn't a good show to watch while going to school or office. 
International Journal of Engineering Applied Sciences and Technology, 2020

Vol. 5, Issue 7, ISSN No. 2455-2143, Pages 157-173

Published Online November 2020 in IJEAST (http://www.ijeast.com)

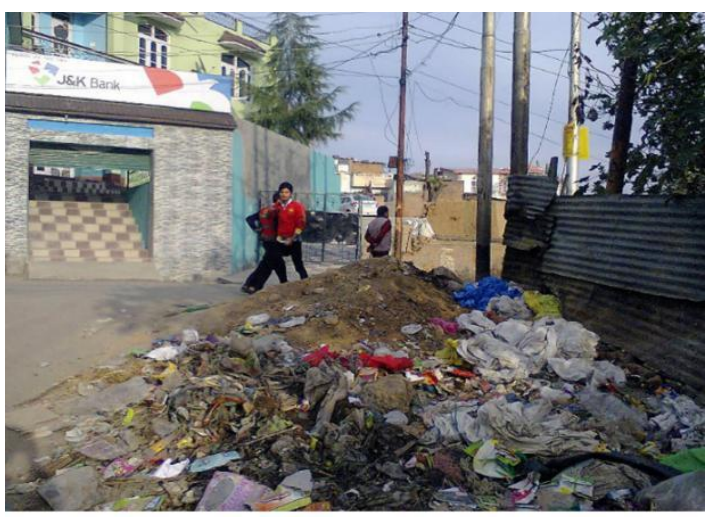

Fig. 7a

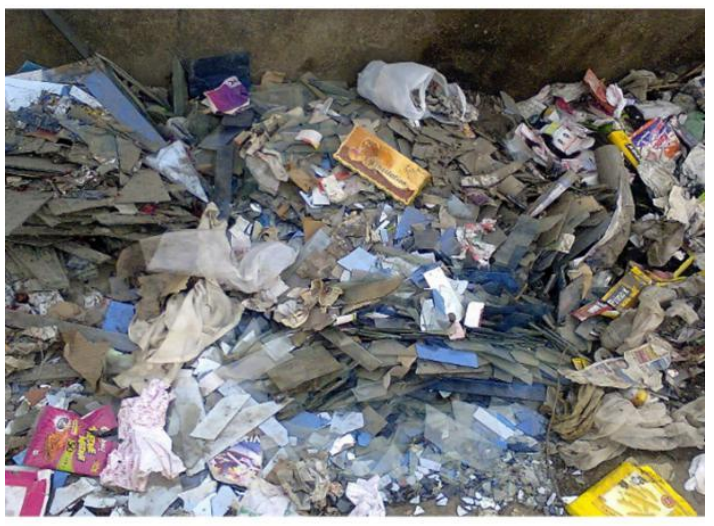

Fig. 7b

Fig. 7: Huge amounts of glass and solid waste lying on the Nagri road, Doda

\section{College Road, Doda, Jammu and Kashmir}

The pictures (Fig. 8) are of the main gate of Government Degree College Doda. This is also a common road for Green Model Higher Secondary School Doda. As is clearly visible in the pictures, there is a colossal amount of refuse scattered on the road which leads to the college as well as to the school. Faculty members and students of the college suffer a lot due to the waste scattered over there. The solid waste and sewage sludge lying there stinks too much which makes it quite difficult uncomfortable for the students as well as the teachers to pass by the road. The waste lying there also troubles the local people whenever they happen to pass by the road on their way to home, school, college and offices. The condition becomes even worse during rain. This aggravates the condition further to troublesome extent. Furthermore, the scattered waste lying there harbours many disease-causing agents which can lead to pandemic and can invite a holocaust of life. The heaped-up garbage can also serve as a hiding place for many dangerous organisms like snakes, scorpions et cetera. Furthermore, during rain, water accumulates into the pits of the damaged road and causes huge water splashing across the road when a vehicle happens to pass by the road. The muddy water makes the students' uniform dirty and scatters many disease-causing agents onto the clothes of the students and the faculty members thereby causing great trouble to them. Several bovines are also often seen visiting the site to quest for food which can lead to another threat. 
International Journal of Engineering Applied Sciences and Technology, 2020

Vol. 5, Issue 7, ISSN No. 2455-2143, Pages 157-173

Published Online November 2020 in IJEAST (http://www.ijeast.com)

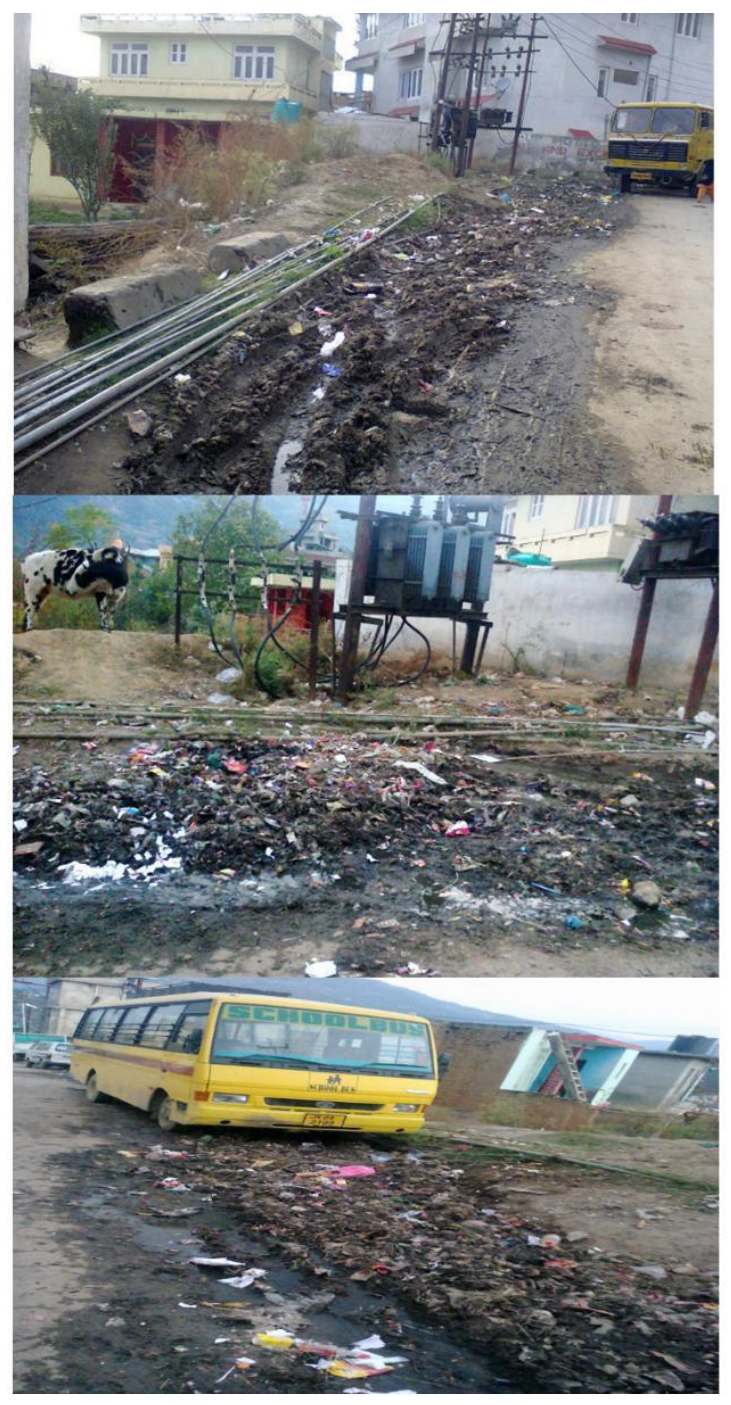

Fig.8: Colossal amount of refuse scattered on the College road, Doda

\section{Bio-Garbage of Doda, Jammu and Kashmir}

The pictures (Fig. 9) are of the living infected and diseased stray dogs which keep wandering here and there on the roads and in the streets of Doda. These dogs are severely infected by serious diseases which may be communicable to human beings. Among other animals, only dogs have been found to be infected with this infection (Dermatophytosis) in Doda region. Such infected disease-causing harmful living organisms can be rightly called as Bio-garbage. They can cause zoonotic infections in humans and other animals also.

Dermatophytosis, also known as Ringworm, is a fungal infection of the skin. It is a fungal skin disease that in dogs is caused by Microsporum canis (70\%), Microsporum gypseum (20\%), and Trichophyton mentagrophytes (10\%). Typical signs in dogs include hair loss and scaly skin Typically it results in a red, itchy, scaly, circular rash. Hair loss may occur in the area affected.

Sometimes these dogs also become infected with Rabies lyssavirus, formerly Rabies virus, which makes the dog mad. The mad dog barks unnecessarily at the people and even bites them badly. This dog bite can cause the disease Rabies in human beings which is quite troublesome and results into another disease called Hydrophobia i.e. fear of water. It is not recommended to kill these dogs but to eradicate them by providing them with proper medical treatment in veterinary hospitals and efforts should be made to isolate them from other dogs and animals to prevent zoonoses.

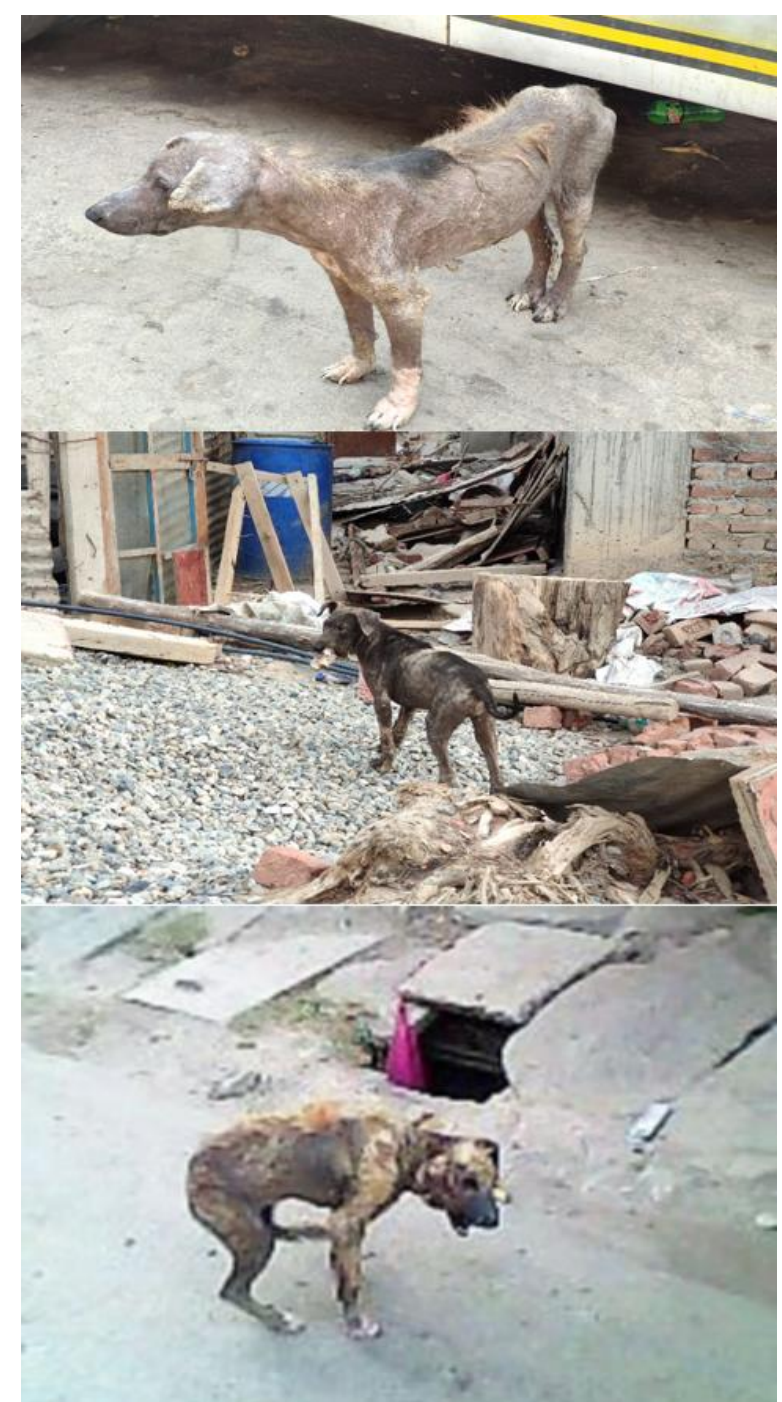

Fig.9: Living infected and diseased stray dogs

\section{Infection of Humans from Solid waste}

There are several potential sources of human infections from solid waste. As indicated, solid waste applied or deposited on soil can result in pathogen transmission to humans. The potential sources are as follows:

- Direct contact with pathogens present in solid waste.

- Aerosolization of pathogens from solid waste.

- Contaminated drinking water.

Pathogenic organisms can infect humans through contact and open skin wounds. This is especially relevant to workers in jobs related to solid waste and others exposed to solid waste, such as scavengers in dumps. These conditions are often prevalent in developing countries in Asia and Africa. Individuals coming in contact with trash or garbage 
can be infected through wounds. The individuals can bring pathogens on their clothing and shoes to the home and infect other individuals. Pathogens can also leach through the soil to water resources. Pathogenic bioaerosols can be released through the air and infect the respiratory system of individuals in the area. The October 27, 2012, New York Times reported on the hazards from an open landfill or dump in Bangalore, India. It stated that 'A stinking mountain of trash, the landfill has been poisoning local waters and sickening nearby villagers.... Trash is India's plague'. The surface disposal of trash directly influences workers and scavengers. As stated in the article, as many as 15,000 waste workers can be affected. In most developed countries, landfills require a liner to protect ground- and surface waters. Under these conditions, especially since the conditions in the landfill are under anaerobic conditions and produce methane, the survival of pathogen is negligible. The concern for water contamination is from inorganic and organic chemicals. There are few data on pathogen survival under lined landfill conditions in developed countries. These conditions are not usually applicable in developing countries. Obire and Aguda (2002) in Nigeria found large numbers of total viable aerobic heterotrophic bacteria for the leachate from a waste dump and an adjacent stream. The leachate counts ranged from $2.5 \times 106$ to $6.5 \times 106$ $\mathrm{CFU} / \mathrm{mL}$, and in the stream, counts ranged from $1.2 \times 106$ to $1.2 \times 107 \mathrm{CFU} / \mathrm{mL}$. The bacteria found in some leachate and stream samples were Bacillus spp., Staphylococcus spp., Klebsiella, and Shigella (Obire and Aguda 2002). FloresTena et al. (2007) reported that they identified 20 pathogenic or opportunistic bacteria in air, 20 from soil, and 11 from leachate in a landfill in Mexico. Although most were enteric, some were respiratory tract pathogenic bacteria. In leachate, the most frequent species were Acinetobacter baumannii, Bordetella spp., Brucella spp., and Escherichia coli var II (Flores-Tena et al. 2007). Aerosolization of pathogens can be from land application of sewage sludge and biosolids (Epstein 1998a, 1998b; Dowd et al. 2000). The extent of pathogen aerosolization depends on the type of application and weather conditions. Typically, biosolids (i.e., treated sewage sludge) in developed countries are either applied in a semisolid form directly to the land and followed by disking or other methods of incorporation into the soil, or liquid biosolids may be sprayed and then disked into the soil. Spraying will tend to disperse pathogens further than if semisolids are applied. Windy conditions could result in greater dispersion of bioaerosols (Epstein 1998). Bioaerosols may be dispersed during the composting of sewage sludge or biosolids. The aerated static pile (ASP) results in much fewer emissions of bioaerosols than the windrow method. In the windrow method, the turning and agitation could result in significant dispersion of bioaerosols containing pathogens. Enclosed systems with proper containment and treatment of the air will not result in emissions containing pathogenic bioaerosols (Epstein 1998b). In many developing countries, fecal matter or raw sewage does not go through a sewage system and is often deposited on land. This could result in dispersion or bioaerosolization of pathogens or direct infection through contact. In the case of incineration of sewage sludge or solid waste, the potential for pathogen infection is to workers. This could result from direct contact as well as inhalation of pathogenic bioaerosols. Workers need to practice good hygienic practices, use protective equipment, and leave clothing and shoes at the workplace (Eliot Epstein, Disposal and Management of Solid Waste, Pathogens and Diseases).

\section{DISPOSAL AND MANAGEMENT OF SOLID WASTE}

The disposal and management of solid waste will generally differ greatly in developed counties than in developing countries. This is partly the result of the absence of infrastructure in developing countries. In developed countries, the presence of waste water handling facilities, septic systems for single homes (i.e., disposal in the absence of sewerage), trash or garbage pickup; incineration with heat recovery and recycling and recovery of paper, metals, plastic, and glass are part of a regulated and controlled infrastructure. In many developing countries, disposal of both human wastes and solid waste is unhygienic, resulting in proliferation of pathogens and diseases. There are opportunities to reduce these conditions through low-cost biological systems and in some cases chemical systems.

The most opportune biological system is composting (i.e., controlled decomposition of organic wastes). In many cases, the compost can be used as an organic fertilizer or for plant nutrients to produce food. If lime is available, especially where soils are acidic as in the case of humid areas, it is both an excellent disinfectant and a source of calcium to plants.

The disposal options are:

- Landfill or Dumps

- Incineration or Burning

- Anaerobic Digestion

- Land Application

- Composting

- Gasification

- Landfill Gas Utilization

- Lime Stabilization

\section{LANDFILLS OR DUMPS}

Landfills today, especially in developing countries, are designed to reduce environmental impacts, such as groundwater contamination and air pollution. Groundwater contamination can principally result from both inorganic and organic chemical contaminants. Inorganic contaminants could be nitrogen and phosphorus from fertilizers, whereas organic contaminants could be pesticides, surfactants, lubricants, and similar compounds. The principal air pollution from landfills is from the discharge of the methane that results from organic material decomposition under anaerobic conditions. Methane is 25 times the air pollutant compared to carbon dioxide. Methane is also an explosive gas and has been known to seep into basements in nearby residences. There have also been incidents of explosions when buildings were built on former landfills. Dumps are places for indiscriminate disposal of human and other solid wastes. They are a source of pathogens both through 
contamination of humans who scavenge the dump and via air pollution. Today, in addition to traditional garbage, a large amount of electronic hardware is disposed. This can result in heavy metal and some organic contamination. Singh, Datta, and Nema (2007) reported that in India uncontrolled land disposal of municipal solid waste (MSW) is common. They noted that groundwater contamination is the most important source of contamination. Financial constraints are the predominant restraint for improvements (Singh, Datta, and Nema 2007). In India in 2007, it was reported that nearly $90 \%$ of the MSW was disposed in open dumps and landfills, creating public health and environmental issues (Sharholy et al. 2008). Uncontrolled dumps and landfills are also common in many other developing countries in Asia, Africa, and South America. As indicated previously, open dumps and landfills are scavenged for usable items. However, the only possible management of these dumps and landfills is soil covering on a daily basis. Groundwater contamination can be avoided by the use of liners.

\section{Incineration and Burning}

Incineration is controlled burning in an enclosed facility. Incineration can be accomplished with energy recovery. Air pollution and disposal of ash can be regulated to minimize environmental impacts. Burning of dumps can be deliberate or the result of methane emission. Workers can initiate a fire by the careless disposal of cigarettes. The United States Environmental Protection Agency (USEPA) reports that the first incinerator was built in New York in 1885. By the middle of the twentieth century, there were hundreds of combustion facilities. Combustion of MSW grew in the 1980s, with more than $15 \%$ of all US MSW combusted by the early 1990s. The majority of the nonhazardous waste incinerators was recovering energy by this time and had installed pollution control equipment. Following incineration, there is still ash to be disposed. The ash is often toxic, containing heavy metals such as vanadium, manganese, chromium, nickel, cadmium, arsenic, mercury, and lead. There has been an attempt to use the ash for road building where it can be sealed to prevent leaching. Alternative technologies are available or in development, such as composting or anaerobic digestion with energy recovery, autoclaving, or mechanical heat treatment using steam. Incinerators are expensive and require control of emissions. However, heat recovery is possible and may result in financial feasibility. Most likely, developing countries would not opt for this way to manage MSW. In developed countries, especially Europe, this may be a feasible option, providing the incinerators can significantly reduce air pollution.

\section{Pyrolysis}

Thermal degradation in the complete absence of oxygen can produce a liquid fuel (but also gaseous flow and solid residues). This option is most suitable for feedstock with a high calorific value and low moisture content such as wood waste and plastic waste.

\section{Anaerobic Digestion}

Anaerobic digestion is the biological decomposition of organic waste by bacteria without oxygen. Anaerobic digestion (also known as bio-methanization) is considered a reliable source of energy in the form of biogas. This can result in the production of combustible methane gas that can be used for heating or operation of engines. Anaerobic Digestion works best for wet wastes, so is most widely used for sewage sludge and for livestock wastes.

In developing countries, Anaerobic Digestion is widely applied at both the small and the community scale, for domestic or community use of the bio-gas. For example, in 2013 there were more than 40 million Anaerobic Digestion plants in the People's Republic of China, nearly 5 million in India and 300,000 in Nepal. Anaerobic digestion is common at wastewater treatment plants in the United States, Canada, and Europe. It is not common in the use of MSW. Anaerobic digestion of solid waste is more complicated. The material is heterogeneous, often containing metal and plastics, which are not digested. Also, the moisture content is low; however, this can be adjusted. Application of Anaerobic Digestion to MSW is challenging. The high solid content, large particle size and inhomogeneous nature of the waste makes process control difficult. It is particularly difficult to apply Anaerobic Digestion to lignin-rich, woody wastes. The digestate remaining can in principle be used as a soil conditioner. This usually requires a relatively long maturation (composting) stage prior to application to land.

\section{Land Application}

Direct land application of human and animal wastes has been used for many centuries. Johansson et al. (2005) discussed the potential risks when spreading anaerobic digested residues on grass silage crops. One of the most comprehensive reviews regarding the sources and fate of pathogens during land application of wastes was reported by Gerba and Smith (2005). They found that more than 150 known enteric pathogens might be present in untreated wastes. Use of untreated or raw wastes for fertilization of food crops is not recommended. They can be used as fertilizer for trees or crops not to be eaten by humans. There are regulations on land application of wastes in the United States, Canada, and Europe. In the United States, the USEPA regulation regarding the various processes that can be used to reduce pathogens prior to land application are cited in 40 CFR 503 (processes to significantly reduce pathogens [PSRPs]) (USEPA 1995). Prior to land application, the waste can be disinfected using anaerobic digestion, composting, or lime stabilization. Human wastes should not be applied near water wells used for drinking or bathing. They should be applied downstream from human habitation. Human wastes applied to land should be incorporated into the soil as soon as possible. Children should not be allowed to play in the area. Workers should change clothes prior to returning home or contacting other persons.

\section{Composting}

Compost is the output of a biological process that converts biodegradable waste to a humus-like material. The 


\section{International Journal of Engineering Applied Sciences and Technology, 2020 \\ Vol. 5, Issue 7, ISSN No. 2455-2143, Pages 157-173 \\ Published Online November 2020 in IJEAST (http://www.ijeast.com)}

principal use is to improve soil quality, as compost improves its biological and physical properties, for example enhancing water retention and resistance to erosion, which is particularly valuable in arid climates. It also has some value as fertilizer. Composting is applicable to a wide range of organic wastes. Residence times are typically longer for lignin-rich hard, woody wastes. Contamination of compost due to household hazardous waste is an issue. In developed countries, regulations allow the use of waste-derived composts for food production, only if clean source-separated feedstock is used. Such materials may be able to meet an end-of-waste protocol. This is the reason for the use of the term 'compost-like output' (CLO) when mixed waste is used as the feedstock (such as from an MBT plant). This will remain a 'waste' and be restricted to non-food applications at sites which obtain a license as waste facilities. Composting requires good process control, to ensure sufficient temperature and retention time to eliminate pathogens and to destroy weed seeds. Open heaps or windrows is the simplest and cheapest method. In-vessel composting uses a variety of proprietary technologies, which claim faster processing times and must be used if the feedstock contains animal by-products. However, open-air or covered windrows are often used for the maturation of the output from in-vessel units. Typically, 50 to $70 \%$ by weight of the MSW generated in developing countries is organic materials suitable for composting. Composting can be facilitated through segregation at source. Decentralized composting systems have been found to work well in many cities in low- and middle-income countries. Home composting is also widely practised all around the world. Vermicomposting, which uses worms, is a popular option, particularly in India.

\section{GASIFICATION}

Gasification was developed for the more efficient recovery of energy from solid fuels such as coal, and to generate a synthetic gas for combustion or as a chemical feedstock. The lack of oxygen reduces the generation of products of incomplete combustion such as dioxins. Gasification is adapted to a range of biomass fuels and to wood wastes. Commercial scale gasification of MSW and industrial wastes has been carried out since the 1990s in Japan and the Republic of Korea. A variety of proprietary technologies have been demonstrated at full scale in North America and Europe since the 1970s, but these have all faced both high costs and operational challenges.

\section{Landfill Gas Utilization}

Methane is produced in landfill sites through the decomposition of organic wastes under anaerobic conditions. Uncontrolled release of methane from landfills is a potential major contributor to greenhouse gas emissions. The migration and accumulation of methane may also pose an explosion and fire risk to the surrounding community. Landfill gas collection is thus a routine part of a controlled landfill operation. The gas may be utilized, either in a gas engine to generate electricity and/or heat, or it may be cleaned and the pressure increased for injection into a natural gas grid or for direct utilization as a transport fuel. Energy recovery from landfill gas has come to be widely implemented in developing countries through climate funding under the Clean Development Mechanism (CDM) of the Kyoto Protocol. This provided an important funding mechanism for many cities, as the payments made for carbon credits from a previous year paid for the current operating costs of the landfill site.

\section{Lime Stabilization}

The addition of lime can be an effective means for pathogen destruction. Most pathogens strive at neutral to slightly acid conditions. Bean et al. (2007) state that liming is a cost-effective treatment currently employed in much USEPA class B biosolids production. Lime stabilization is a simple process. Its advantages are simplicity and low cost. The USEPA stated that the waste must reach a $\mathrm{pH}$ of 12 for 2 hours to be effective in reducing pathogens. During lime treatment, ammonia, which is a disinfectant, is released. Furthermore, heat is also produced. This combination of ammonia and heat release can result in pathogen destruction. For example, India has an abundance of lime primarily used for cement production. Some of this lime could effectively be used for waste disinfection.

\section{CONCLUSION}

Waste has been a major environmental issue everywhere including the Doda region of Jammu and Kashmir, due to the increase in the population and the standard of living of people. There has been rapid increase in the generation of Municipal Solid Waste due to increased urbanization. High standards of living of ever-increasing population have resulted in an increase in the quantity and variety of waste generated, particularly in urban areas. It is now being realized that if waste generation continues recklessly at this very pace, then it would become rampant and alarming very soon and possibly beyond rectification. Therefore, Management of solid waste has become very important in order to minimize the detrimental and lasting aftermaths of solid waste.

\section{Acknowledgement}

The authors acknowledge the parental institutions for their timely support.

\section{REFERENCES}

1. Epstein E. (2015). Disposal and Management of Solid Waste, Pathogens and Diseases, CRC Press, Taylor \& Francis Group.

2. Rasool N. and Balwan WK. (2020). Municipal solid waste characterization and quantification as a measure of effective management: First case study from area. International Journal of Research in Applied, Natural and Social Sciences, 8(7): pp1-6.

3. Tchobanoglous G. and Kreith F. (2002). Handbook of Solid Waste Management, The McGraw-Hill Companies 
4. Kumar S. (2016). Municipal Solid Waste Management in Developing Countries, CRC Press, Taylor \& Francis Group.

5. Worrell AW. And Vesilind PA (2012). Solid Waste Engineering, Cengage Learning.

6. Chandrappa R. and Das BD. (2012). Solid Waste Management, Principles and Practice, SpringerVerlag Berlin Heidelberg.

7. UNDESA-World Social Report (2020). Urbanization: Expanding Opportunities but Deeper Divides.

8. United Nations (2018d). World Urbanization Prospects: The 2018 Revision.

9. What a Waste 2.0 (2018). A Global Snapshot of Solid Waste Management to 2050, World Bank Group.

10. Solid Waste Management in the World's Cities (2010). Water and Sanitisation in the World's Cities, United Nations Human Settlements Programme, UNHABITAT.

11. Global Waste Management Outlook (2015). International Solid Waste Association, United Nations Environment Programme. 